\title{
Bonding and bridging social capital in family firm internationalization
}

\author{
Emanuela Rondi - Francesco Debellis - Alfredo De Massis \\ Antonello Garzoni
}

\begin{abstract}
Purpose of the paper: This paper aims to study how family firms manage their Global Value Chain (GVC). In particular, we investigate how family firms are able to keep control over operations outsourced to foreign partners. Prior research focused on understanding how firms control their GVC has mainly concentrated on large multinational enterprises. However, while large multinational enterprises can overcome transaction cost complexities by exploiting their superior legitimacy and power control over weaker firms, family SMEs often do not have that amount of power due to financial and managerial constrains. In this study, we thus conceptually examine a unique characteristic that can help family SMEs to overcome resource limits and gain control over the GVC: their distinctive social capital.

\section{Methodology: Conceptual}

Findings: Family SMEs can exploit their superior social capital in order to build long-term relationships based on trust with foreign partners, thereby being able to control their GVC without legally owning it.

Research limits: The study is conceptual, future research should test the model and empirically examine the theorized mechanisms. Social capital is only grasped according to its positive side and in relation to cohesion, future research should examine the negative side of social capital and the role of conflict in our model. Finally, family firm heterogeneity is currently neglected.

Practical implications: Our study offers insightful managerial suggestions to family firm executives and their foreign partners in terms of design and governance of their GVC.

Originality of the paper: Our study offers theoretical and managerial contributions to the current understanding of family firm internationalization beyond exports.
\end{abstract}

Key words: family firms; internationalization; global value chain; social capital; SMEs

\section{Introduction}

In the current fierce globalized market, the ability to manage the value chain at global level is a critical success factor for any organization. Suggestions for the governance of the Global Value Chain (GVC), i.e. "the process by which technology is combined with material and labor inputs, and then processed inputs are assembled, marketed, and distributed" 
sinergie Vol. 38, Issue 2, 2020

(Kogut, 1985, p. 15) are provided in the Global Factory model developed by Buckley and Ghauri (2004). According to this model, firms need to find the optimal combination of internalization and external contracts in a variety of geographically dispersed markets, so as to minimize the sum of production and contracting costs (Kano et al., 2020; Verbeke and Kano, 2016). Specifically, the model suggests that firms should finely slice their GVC activities, by increasing internalization ${ }^{1}$ of knowledge and outsourcing of operations (Buckley and Strange, 2015). The GVC involves various types of knowledge and expertise embodied in the human capital as well as the social capital embedded in the relationships with foreign partners (Buckley and Strange, 2011). Therefore, the international governance structure cannot depend only upon financial comparative transaction costs, but it becomes important to investigate how certain aspects, such as social capital, influence the process through which a firm controls its GVC.

Social capital, i.e. "the goodwill available to individuals or groups", lies in the structure and content of the actor's social relations (Adler and Kwon, 2002, p. 23). Unlike other forms of capital, social capital is not located in the actors, hence it cannot be possessed. Instead, it lies in the relationships between actors. Considering the importance of relational governance mechanisms in determining the success of GVC control (Enderwick and Buckley, 2017), it is surprising that prior studies on GVC have almost exclusively focused on large multinational enterprises neglecting smalland medium-sized firms, particularly those led by a family where social capital is a deeply embedded resource and extremely difficult to imitate (De Massis et al., 2013; Dess and Shaw, 2001). In fact, small and medium family firms (family SMEs) emerge as particularly crucial to investigate the GVC, since they are the majority of firms worldwide (De Massis et al., 2018) and cannot benefit from superior legitimacy and power control over weaker firms as large multinational enterprises do (Carney, 2005). Therefore, their financial and managerial constrains induce family SMEs to adopt different strategies to compete in the global market (Cesinger $e t$ al., 2016; Hennart et al., 2017) and this is likely to happen also in the design and control of their GVC.

In this study, we address the following research question: How can social capital help small- and medium-sized family firms control their GVCs? We investigate the governance of the GVC by building on the current understanding of family firm social capital. Therefore, we develop a conceptual framework to explore how family SMEs and their members control the GVC by leveraging social capital, thereby overcoming resource constraints (Fernández and Nieto, 2005). Specifically, we examine the key leverages of bonding (internal) and bridging (external) social capital of both the family and the organization through which family SMEs are able to keep control over their GVC without legally owning it. Building longterm relationships both internally with their employees and externally with members of foreign partners, family SMEs are able to build a global 
network of relationships that allows them to control their value chain through social capital in the long run (Puthusserry et al., 2020).

Our study offers two main contributions to the literature on family firms' internationalization. First, while prior research has mainly examined exports (De Massis et al., 2018), we dig into the higher complexity that family firms have to face when they internationalize "beyond exports" (Stoian et al., 2018). Second, we bring the Global Factory model (Buckley and Ghauri, 2004) into the context of family SMEs, thereby exploring the role of social capital as a critical driver of the GVC governance. Therefore, despite the many potentially restraining features usually associated with family SMEs that might jeopardize their international growth (Pukall and Calabrò, 2014), we conceptually highlight how family firms can successfully compete in the global context through their distinctive social capital.

\section{Internationalization of family firms}

Family firms, i.e. firms where a family has the ability to influence the vision of the business and the intention to transfer it across generations (Chua et al., 1999; De Massis et al., 2014) are the most ubiquitous form of organization worldwide (De Massis et al., 2018) and are characterized by distinctive traits that make their internationalization path unique (Arregle et al., 2017). While organizations not involving a family usually make decisions about internationalization based on potential financial gains and losses, family firms face a "mixed gamble" (Alessandri et al., 2018; Gomez-Mejia et al., 2018) by weighting potential gains and losses from their strategic options in two non-fungible currencies, financial wealth and socioemotional wealth. Specifically, socioemotional wealth is defined as the pool of non-financial aspects of the firm that meet the social and affective needs of the family (Gómez-Mejía et al., 2007), such as the willingness to maintain family control (Chua et al., 1999; Schulze et al., 2003) and passing the baton to future generations (Berrone et al., 2012). Given the coexistence of financial and non-financial considerations in their decision-making (Campopiano and Rondi, 2019; Kotlar et al., 2018), family firms represent a unique type of organizations that weigh risks related to internationalization differently from their non-family counterparts (e.g., Liang et al., 2014).

Prior research on family firms' internationalization has mainly focused on exploring whether they internationalize more or less than their non-family counterparts, producing mixed results (e.g., Kontinen and Ojala, 2010; Pukall and Calabrò, 2014). On one hand, some scholars highlighted that family firms internationalize to a greater extent due to their long-term vision (Claver et al., 2009), "patient capital" (Carr and Bateman, 2009), social capital (Arregle et al., 2007), and considering it as an opportunity to involve more family members in the firm (Zahra, 2003). On the other hand, the paucity of financial and managerial resources (Carney, 2005), unwillingness to accept non-family expertise and the fear of losing firm control (Graves and Thomas, 2008; Kontinen and
Emanuela Rondi Francesco Debellis Alfredo De Massis Antonello Garzoni Bonding and bridging social capital in family firm internationalization 
sinergie Vol. 38, Issue 2, 202

Ojala, 2010) conventionally associated to family firms, are considered as barriers to their internationalization. According to recent studies (Arregle et al., 2017; De Massis et al., 2018), the inclusiveness of results on whether family firms internationalize more or less than non-family firms is due to an ill-posed question, because every firm has its own optimal level of internationalization. Thus, research on distinction between family and non-family firms needs to focus more on "how" things are done, rather than just on "what" decisions are made (Reuber, 2016).

Although research on family firm internationalization is certainly gaining momentum, several limits remain. First, internationalization has been investigated mainly in relation to exports, neglecting challenges related to different entry modes (De Massis et al., 2018). Internationalization beyond exports can provide several benefits (Lu and Beamish, 2001), by allowing firms to gain above-normal returns in international markets, exploiting firm-specific advantages (Buckley and Casson, 1976), and enabling arbitrage choices in input and output markets (Hennart, 1982). However, entry modes beyond exports involve higher coordination complexities (Stoian et al., 2018), information asymmetries and all the liabilities of operating in new host markets, significantly raising governance costs (Hitt et al., 1997; Tallman and Li, 1996). By focusing only on exports, prior literature has thus missed to give an explanation on how family firms face all these complexities, as well as how these firms approach and manage the relationships with foreign partners in order to access critical resources not available in their domestic market.

Second, the most adopted model to describe internationalization process in family firms is the Uppsala model (Johanson and Vahlne, 1977, 2009), suggesting that firms usually should first be established in their domestic market, then start with exports in psychic closer countries by adopting a sequential entry-mode process of joint experiential learning and gradual expansion, and later switch to other further countries with stronger commitment equity modes. However, in a market where technological innovation and digital communication reduce geographical distance for many sectors and compress the time frame necessary to stay ahead of competitors, thinking about internationalization as a growth option to develop only after having thoroughly established in the domestic market, risks to be detrimental for family firms. Therefore, in order to advance research on the field, we argue that it is necessary to adopt other theoretical frameworks developed in international business research, in this case the Global Factory model (Buckley and Ghauri, 2004), by taking into account the specific characteristics of the family SMEs.

\section{The Global Factory model}

The combined effect of flexibility needs and downward pressure on prices spurs organizations to pursue international outsourcing (Buckley, 2009a). In order to be successful in the current rapidly evolving scenario, firms need to be capable of fine-slicing their activities and altering internalization and externalization decisions for activities that were 
previously locally bounded and that could only be internally controlled. In fine slicing their activities, firms can compare every element with market alternatives and outsource them when transaction costs are lower than the costs of internalization (Buckley, 2009b).

The Global Factory model developed by Buckley and Ghauri (2004) draws on internalization theory (Buckley and Casson, 1976), which is a theory based upon a comparison of the relative efficiency of different cross-border governance mechanisms, that highlights the relative costs and benefits of coordinating geographically dispersed activities through vertical integration or by recurring to the external market (Buckley and Casson, 1976; Hennart, 1982; Rugman, 1981). According to the Global Factory model, firms should thus focus their main efforts on knowledgeintensive activities, i.e. pre-production (e.g. conceptualization, R\&D) and post-production (e.g. marketing, after-sales service) activities (Strange and Humphrey, 2019), while externalizing all other operations in a variety of geographically dispersed markets (Verbeke and Kano, 2016). By externalizing activities, firms can concentrate on their core competencies (Prahalad and Hamel, 1990), taking advantage of complementary resources and capabilities owned by external suppliers (Gottfredson et al., 2005). So, knowledge-intensive activities are internalized, whereas productionrelated activities are more frequently outsourced ${ }^{2}$. Therefore, the Global Factory combines internal management and external contracting of activities across a diversity of locations, with the aim of minimizing the sum of production and control costs. According to Enderwick and Buckley (2017, p. 547), the Global Factory can thus be defined as a network "at the heart of which are complex flows of knowledge, intermediate products, and management skills". However, the control of all the externalized activities is critical for determining the success or failure of the firm. Despite the importance of keeping control over the value chain and the potential absence of legal ownership on externalized activities, literature is silent on the mechanisms by which firms might control the externalized operations over their GVC (Strange and Humphrey, 2019).

When a firm recurs to foreign externalization, must deal with the challenge of managing relations across cultural, institutional and geographic boundaries, with consequent difficulties to monitor foreign partners' actions. In order to overcome these difficulties, the need for structuring detailed long-term contracts emerges. However, contracts executed under conditions of uncertainty are incomplete by nature, due to bounded rationality, and require a certain level of adaptation over time (Williamson, 1979). Therefore, in a relationship between firms across countries based on a long-term perspective, it is more likely that the main reference point is the entire relation and its development over time, rather than the contract (Williamson, 1991). The classic internalization

$2 \quad$ As explained by Mudambi (2008), firms combine the comparative advantages of geographic locations with their own resources and competencies to maximize their competitive advantage. This strategic evaluation results in a "smiling curve" of value creation where the activities at the end of the GVC are largely internalized and located in advanced market economies, while those in the middle of the value chain are outsourced and moved to emerging market economies.
Emanuela Rondi Francesco Debellis Alfredo De Massis Antonello Garzoni Bondino Garzoni social capital in family firm internationalization 
sinergie Vol. 38, Issue 2, 2020

theory (Coase, 1937) is based on the assumption that in the assessment of location factors, multinational enterprises emerge when the benefits of internalization exceed their costs (Hennart, 1982; Rugman, 1980; Williamson, 1975). However, studies built on internalization theory have devoted little attention to the governance mechanisms based on the interactions among actors so far, such as networking among individuals or competition/cooperation among firms (Enderwick and Buckley, 2017). In particular, following (Buckley and Strange, 2011), we identify three main complexities related to the control of externalized activities: information costs, i.e. the costs of acquiring and transmitting information with the strategic partner; coordination costs, which refer to the costs of communication about combined actions of partners; and motivation costs, the costs of supervision and interest alignment between partners. Considering that these complexities cannot be managed only through formal contracts, the presence of social capital that eases the formation of trust and mutual forbearance between partners is crucial for the successful governance of the GVC. Therefore, considering the role of relationships and social capital is crucial to understand the establishment of relational governance mechanisms for successfully controlling the GVC (Enderwick and Buckley, 2017). In addressing this issue, we consider the investigation of the GVC in the context of family SMEs - where social capital is a key resource (Dess and Shaw, 2001) - as an insightful starting point.

\section{Social capital of family firms}

Social capital "lies in the structure and content of the actor's social relations. Its effects flow from the information, influence, and solidarity it makes available to the actor" (Adler and Kwon, 2002, p. 23). Social capital emerges from relationships among actors and can be used to pursue financial and non-financial goals (Arregle et al., 2007). Its relational nature makes the study of social capital particularly intriguing in the interaction among individuals, groups and organizations, particularly in the context of internationalization. The goodwill that organizational actors have toward each other as well as toward members of other organizations is a valuable resource for the organization to which they belong, rare and costly to imitate, therefore provides the basis for competitive advantage (Barney, 1991).

Scholars have explored the sources and effects of social capital according to two main views: bonding and bridging. A focus on internal relationships within a collectivity foregrounds bonding social capital, focusing on the cohesive links of actors in a community (Coleman, 1988). Usually associated with strong ties, embeddedness, closure and high network density; bonding social capital is represented by relationships that emerge in closed circles as families. Through these relationships, actors are able to build trust, spurring collectivism and commitment. Conversely, bridging social capital relates to the direct or indirect relationships that actors develop across different communities (Burt, 2000).

Social capital contributes to shaping the distinctive traits of family 
firms according to the systemic interactions between the members of the family and the business (Sirmon and Hitt, 2003). In fact, 'the family is a source, builder and user of social capital' (Bulboz, 2001, p. 130), and family firms are characterized by the presence of intense social relations. Family businesses are influenced by family involvement that, like family relationships, has the intent to endure (Sorenson, 2013). The family provides the ground of moral behavior that guides cooperation and coordination in family firms and sets principles of reciprocity (Bulboz, 2001). Since families are enduring social entities across generations, they can rely on lasting shared meanings including values, norms and beliefs (Erdogan et al., 2020) to develop and shape their social capital (Sorenson, 2013). Families are therefore able to create dense forms of social capital through the development of strong internal relationships and kinship (Pearson et al., 2008). As highlighted, social capital in family firms is a deeply embedded resource, tacit and extremely difficult to imitate (Dess and Shaw, 2001). For these reasons, it is considered a source of competitive advantage for family businesses and a potential lever for strategic organizational processes as internationalization.

Family businesses share stakeholders between the business and the family (Sorenson, 2013). Arregle et al. (2007) introduce two forms of social capital in family business: family social capital and organizational social capital. Family social capital develops among family members and is considered the most enduring and powerful form. The family provides support, and the care granted by parents to children is reciprocated with gratification, love and promise of future care (Bulboz, 2001). The family works as a team wherein members benefit from resources as solidarity, influence and information (Arregle et al., 2007). The family social capital involves actors that are members of the family, although they may not be involved in the firm. The organizational social capital is 'a resource reflecting the character of social relations within the firm' (Leana and Van Buren, 1999, p. 538), it enables access to external resources and cohesion within the organization. The construct of the organizational social capital sheds light on the need of firms to rely on their internal actors to access resources beyond their organizational boundaries, particularly those resources that could not be purchased. In fact, the organizational social capital increases the availability of knowledge, information, trust and connections with institutions that may have direct effect on organizational performance.

Scholars have also investigated how the family social capital influences the development of organizational social capital in family firms (Arregle et al., 2007). In this attempt, Sharma (2008) intersects these constructs with bonding and bridging social capital. The framework that she develops depicts the bonding and bridging relationships that can occur within and across the family and business systems, leading to a configuration of four distinctive types of social relations (family bonds, business bonds, family bridges, business bridges) that benefit the family firm through flows of social capital accruing from the diverse links.

Although these studies are particularly relevant for the understanding of social capital in family firms, conceptual examinations have been
Emanuela Rondi Francesco Debellis Alfredo De Massis Antonello Garzoni Bonding and bridging social capital in family firm internationalization 
sinergie Vol. 38, Issue 2, 2020

limited to a single-family firm so far. However, family firms do not exist in isolation and their strategic activities are often carried out in collaboration with other firms (e.g., Feranita et al., 2017). This is particularly true for the internationalization process, where family firms need to rely mostly on relationships rather than formal governance mechanisms to control externalized activities of their GVC. Therefore, we argue that it is necessary to extend the exploration of family firm social capital beyond the boundaries of a single organization to unveil the potential of social capital in cross-organizational collaborations, particularly in the process of building a GVC.

The organizational social capital of family firms was found to be a determinant in the development of interorganizational collaboration and investments in new ventures (Zahra, 2010). However, the role of family firms' social capital in interorganizational collaborations has received limited attention by prior research. Recently, Zahra (2018) has shown that family businesses with high organizational social capital and technological capabilities internationalize more than non-family-controlled firms. Therefore, research has started highlighting the importance of exploring social capital in family business, and we aim to enrich this debate by introducing a conceptual framework of family SMEs' governance of the GVC.

\section{Extending the global factory model to family firms: the crucial role of social capital}

Family SMEs are more able to internally rely on relational contracting than their counterparts by leveraging both the family and the organizational social capital. Such characteristic allows them to reduce monitoring costs and opportunistic hazards, by providing safeguards based on mutual trust (Eddleston et al., 2010; Debellis et al., 2020). Scholars have found family firms to be perceived as having more trustworthy policies, practices, and frontline employees than non-family businesses (Orth and Green, 2009). The long-term orientation of family firms, due to the strong identification of family members with the firm, discourages opportunistic behavior and fosters mutual forbearance, necessary for maintaining strong relations with strategic partners (Casson, 1989) as well as preserving their reputation (Eddleston et al., 2010). Social capital enhances cooperation and goal alignment, facilitating information exchange and the commitment of organizational partners, so that the need for control-based approaches decreases (Sundaramurthy, 2008).

We argue that in building their GVC, particularly when collaborating with other family firms, family SMEs are able to internationally mirror internal governance mechanisms, as those enabled by the family and organizational social capital. This is due to two main reasons. First, despite the cultural distance that might separate organizations collaborating internationally, families in collaborating businesses are more likely to share their attitude toward long-term and trust-based relationships that are the foundation for the emergence of bonding and bridging social capital (Adler 
and Kwon, 2002). Second, since family firms take into account financial and non-financial goals when making decisions, also their approach toward fine-slicing decisions of internalizing versus externalizing their activities, maybe internationally, is affected by non-financial assessments. Therefore, in these situations, family SMEs do not only consider cost optimization, need for monitoring and control or potential issues arising from bribery of international partners. Indeed, the social capital that family SMEs are able to generate in the relationships with their international partners is likely to exert a positive influence on their willingness to outsource. The structural and efficiency benefits of international partnerships are mainly based on substitute contractual safeguards (Poppo and Zenger, 2002), such as trust, flexibility, interest alignment and mutual forbearance. Family SMEs have advantages in terms of the ability to exercise mutual forbearance, being committed to cooperate and willing to preserve and enhance their reputation, which lead to further cooperation benefits. So, although family firms may not be legally structured as multinational enterprises, they can exert control on international flows of intermediate goods and foreign operations by relying on a configuration of long-term social capital types with their foreign partners.

Following this reasoning and building on the current understanding of GVC and social capital in family firms, we conceive four different types of social capital in the international collaboration of a family SME with a family foreign firm partner - as illustrated in Figure 1.

Fig. 1: Social Capital Configuration of Family Firm's Collaboration in the GVC

Focal Family Firm

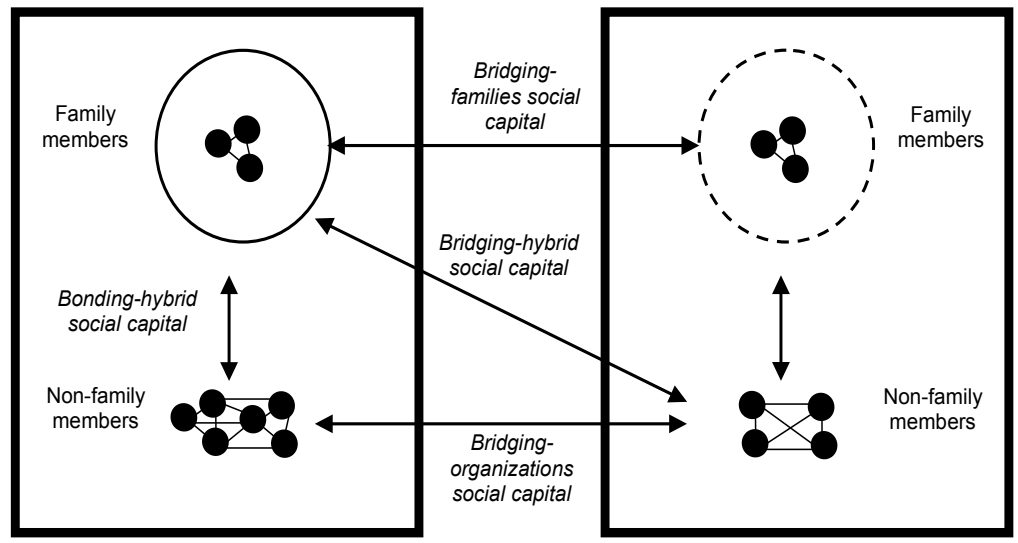

Source: Our elaboration

The foreign collaboration between two family firms can rely on the already theorized internal social capital within each family firm (bonding) arising from the relationship between the family and the organization members (hybrid) - we define this type Bonding-hybrid social capital. Scholars have already investigated resources accruing from the interplay of the family and the business members (e.g., Arregle et al., 2007;
Emanuela Rondi Francesco Debellis Alfredo De Massis Antonello Garzoni Bonding and bridging social capital in family firm internationalization 
sinergie Vol. 38, Issue 2, 2020

Sharma, 2008). However, in our framework - focused on international collaborations - this form of social capital acts as the baseline for ensuring a link between the leading family and organizational members, that are likely to interact with members of the international partner. Building a bonding hybrid social capital is thus crucial not only for the internal governance of the family firm, but also to lubricate external collaborations (Zahra, 2010). In fact, the bonding hybrid social capital plays a key role in international collaborations, where the interaction across organizations as building blocks of the value chain relies mostly on the activities carried out by business members (either or not family members). Ensuring trust, commitment and long-term relationships between the family and its business members allows to develop policies and practices aligned to the family lead.

The bonding hybrid social capital type within each organizational boundary spurs three other types of social capital at the crossroad of the two collaborating family firms: the bridging-families social capital, the bridging-organizations social capital, and the bridging-hybrid social capital. The bridging-families social capital arises when both firms are family led and the two families are able to develop fruitful relationships. The shared grounding principles that guide the conduct of each family system - such as long-term orientation, transgenerational leadership, mutual trust and reciprocity - boost the development of positive relationships between the two families that endure over time and are likely to differ from potential international collaborations with non-family counterparts (Cesinger et al., 2016). The grounding principles of the family systems, although nonidentical, are similar across cultures and can act as bridges for culturally distant collaborations.

The Bridging-hybrid social capital is generated through the relationship between the family members and the non-family members of the partner firm. Indeed, the stability, trust, cohesiveness and tradition that exist in certain family firms (Khanin et al., 2012; Rondi et al., 2019) make nonfamily members feel part of the family. Kin ties among family members are thus likely to engender strong social bonds with non-family employees of the partnering organization (Berrone et al., 2012). The involvement of non-family members in the decision-making process, who benefit from the family's trust, possess the market knowledge and relevant network which are essential to build the foreign partnership.

Finally, the link between the business and the family may also increase non-family members' commitment and identification with the family firm by motivating their responsible stewardship behaviour and psychological ownership. Indeed, despite the different organizational objectives, their core organizational values are compatible and mesh to each other, particularly through long-term collaboration. So, the longer the strategic relationship between firms endures and non-family members are employed into the family firm, the stronger the Bridging-organizations social capital will be.

In sum, the internalization theory suggests that the risks of partners' opportunistic behaviour, and the consequent high costs of coordination costs push firms to opt for a vertical integration rather than outsourcing. However, family firms, due to the four unique types of social capital, 
can overcome these complexities and opt for further externalization of activities, thereby reducing the amount of fixed costs, which are high in case of vertical integration (Casson, 1989). Therefore, due to family idiosyncratic characteristics such as trust, reputation and long-term commitment, the risk of opportunistic behaviour is reduced and it becomes possible to build up over time a successful strategic partnership based on relational governance aimed to gain full control of the GVC, even in absence of legal ownership.

\section{Discussion}

By grafting the conceptual lenses of social capital in the exploration of family firm internationalization, we have argued that family SMEs are able to compensate their lack of resources necessary to scale up their value chain globally, by building bonding and bridging types of social capital with their foreign partner. By doing so, we conceptualize the existence of an internal and external social capital for each of the partnering family firms, leading to a configuration of four types of social capital emerging from the relationships among family and non-family members. Stemming from our conceptual framework, we argue that the development of such types of social capital acts as lubricant of the foreign collaboration and allows family SMEs to compensate their lack of legal ownership and resources to enforce legal contracts.

Our study offers two main contributions to deepen the understanding of internationalization of family firms. First, we address the call for further investigation of a wider range of entry modes through which family firms internationalize beyond exports (De Massis et al., 2018; Stoian et al., 2018). We do so by digging into the development of the GVC by family firms that fine-slice their activities through externalization, thereby embracing the Global Factory model (Buckley and Ghauri, 2004). More specifically, we contribute to the literature on family firm internationalization by extending the Global Factory model to the idiosyncratic context of family firms, taking into account its distinctive traits. While large multinational firms have more financial resources at their disposal and can recur more to vertical integration (i.e. internalization) as well as exploit their superior legitimacy and power in controlling GVC activities, we bring theoretical evidence on the important differences of GVC in family SMEs.

Second, we leverage the idiosyncratic ability of family SMEs to build strong social capital within their organization (Arregle et al., 2007 Sharma, 2008) and extend it to the process of internationalization in building both bonding and bridging social capitals among family and non-family members of the different organizations across borders. Family firms' social capital is crucial in the process of internationalization; indeed, evidence shows that family firms with strong social capital in the host country internationalize more than non-family firms (Zahra, 2018). We argue that despite the cultural distance between firms operating in different contexts, the presence of families in SMEs creates a common ground for collaboration, being likely to share common principles of building strong
Emanuela Rondi rancesco Debellis Alfredo De Massis Antonello Garzoni Bonding and bridging social capital in family firm internationalization 
sinergie

Vol. 38, Issue 2, 2020

community within their organization, having long term orientation, and commitment to low turnover. All these aspects spur the development of strong social capital within and between organizations, thereby ensuring the ability of family SMEs to exert control over the value chain, without requiring the legal ownership of foreign subsidiaries. Specifically, the configuration of the four types of social capital identified is coherent with the concept of group social capital, wherein bridging and bonding relationships developed by individuals are able to nurture the functioning of the whole group (Oh et al., 2004). In this case, we adopt a broader perspective on the collaboration between two organizations and explore the mutual benefit of building strong social capital. Such approach can be broadened even further, by analysing the network of collaborations that a focal family firm is able to develop in designing, configuring and controlling its GVC.

Although our investigation is grounded in the assumption that the two collaborating firms are led by families, our framework offers insights also on the international collaboration of non-family firms. In case either business does not involve a family, the hybrid bonding, hybrid bridging and families bridging social capital are less likely to hold. This extension of our conceptual framework offers insight for the reasons why nonfamily firms need to further formalize their foreign collaborations. The absence of family principles and long-term orientation leaves employees of businesses operating globally to individually develop relationships with foreign partners. However, such relationships are exposed to higher turnover, stronger financial goals and short-term orientation, all stressors that are likely to compromise the development of enduring social capital across organizations.

\section{Limitations and future research directions}

Although our study deepens the understanding of family firm internationalization, it is not free of limitations. First, we conceptually theorize about foreign collaborations among family firms, but we do not rely on empirical evidence to test it. Further research is required to explore the impact that social capital has on family business internationalization, for example addressing how previous collaborations with international partners shapes future family business international operations.

Second, we assume the abundance of social capital as a distinctive trait within the family and the organizational boundaries. However, family business research has shown that families might have conflicts that spur the development of negative relationships, and nepotism and parental altruism may lead non-family members to perceive a sense of injustice that engenders mistrust toward the family (Lubatkin et al., 2005; Schulze et al., 2003). Future research could then examine the impact that social capital within each group (e.g. the family) has on the social capital of other groups (e.g. the organization, the partnership).

Third, our conceptualization of social capital is merely positive, as a resource whose accrual is beneficial to the family firm. However, studies 
have started developing concern on the dark side of social capital, claiming that having 'too much of a good thing' could be harmful for organizations (Gargiulo and Benassi, 1999). In particular, scholars explored the redundancy in relationships, assessing that while it is very beneficial for individuals in a group to develop ties with otherwise disconnected actors to access novel resources - e.g. through network brokerage (Kwon et al., 2020), having an excessively closed network of ties, where every individual is connected to each other, can be inefficient. Scholars could analyze whether there is an optimum level of relationship development across businesses as well as of social capital development in the internationalization process of family firms.

Fourth, we consider family business as a homogenous category of firms that can rely on strong internal relationships among its members, however not all family businesses are the same. Heterogeneity among family firms is increasingly receiving attention and research is showing the relevance of taking into account not only their diversity from non-family counterparts but also nuances within the same category. We build our argument by considering family SMEs, wherein the overlap between the family and the organization is likely to be high. In this case, the relationships within the family and among the family and non-family members are likely to be intense, allowing each member of the organization to interact with the members of the owning family and contribute to the development of bonding-hybrid social capital. Conversely, in large family firms the overlap of the family, the ownership and the management of the business can be scarce, with potential consequences on the development of relationships among the members of the different groups and the related social capital. What happens to the bonding-hybrid social capital in a large family firm? What are the consequences of having lower levels of bonding-hybrid social capital on the bridging forms of social capital in an international collaboration? Does a large family firm behave more similarly to a nonfamily firm in managing international collaborations in absence of strong bonding-hybrid social capital? These are questions that future research could address by delving into the underlying mechanisms behind this phenomenon.

Furthermore, within the category of family SMEs, heterogeneity might arise from the presence of different levels of family social capital and/or weak ties among family members, with consequences for the development of bonding-hybrid social capital. Contributions may arise from the investigation of the heterogeneity of family firms and its implication for their internationalization processes, such as how heterogeneity of ties' strength within a family affects the development of different forms of family SMEs' social capital and what are the implications for international collaborations. Similarly, heterogeneity among family firms can be relevant for the business side. Although in our conceptual development we only consider families with a single business, research on family firms is increasingly devoting attention toward those families that own a portfolio of businesses (Le Breton-Miller and Miller, 2018). What happens to the internationalization process when a business family owns multiple businesses? Does the social capital of the family erode or increase its 
Sinergie Vol. 38, Issue 2, 2020

beneficial effects when leveraged by multiple businesses in the process of internationalization? Addressing these questions has the potential to further advance current understanding of the phenomenon of family firms' internationalization.

\section{References}

ADLER P.S., KWON S.W. (2002), "Social capital: Prospects for a new concept", Academy of Management Review, vol. 27, n. 1, pp. 17-40.

ALESSANDRI T.M., CERRATO D., EDDLESTON K.A. (2018), “The mixed gamble of internationalization in family and nonfamily firms: The moderating role of organizational slack", Global Strategy Journal, vol. 8, n. 1, pp. 46-72.

ARREGLE J.L., DURAN P., HITT M.A., VAN ESSEN M. (2017), "Why is family firms' internationalization unique? A meta-analysis", Entrepreneurship Theory and Practice, vol. 41, n. 5, pp. 801-831.

ARREGLE J.L., HITT M.A., SIRMON D.G., VERY P.(2007), “The development of organizational social capital: Attributes of family firms", Journal of Management Studies, vol. 44, n. 1, pp. 73-95.

BARNEY J. (1991), "Firm resources and sustained competitive advantage", Journal of Management, vol. 17, n. 1, pp. 99-120.

BERRONE P., CRUZ C., GOMEZ-MEJIA L.R. (2012), "Socioemotional wealth in family firms: Theoretical dimensions, assessment approaches, and agenda for future research", Family Business Review, vol. 25, n. 3, pp. 258-279.

BUCKLEY P.J. (2009a), "The impact of the global factory on economic development", Journal of World Business, vol. 44, n. 2, pp. 131-143.

BUCKLEY P.J. (2009b), "Internalisation thinking: From the multinational enterprise to the global factory", International Business Review, vol. 18, n. 3, pp. 224-235.

BUCKLEY P.J., CASSON M. (1976), The future of the multinational enterprise, Macmillan: London.

BUCKLEY P.J., GHAURI P.N. (2004), "Globalisation, economic geography and the strategy of multinational enterprises", Journal of International Business Studies, vol. 35, n. 2, pp. 81-98.

BUCKLEY P.J., STRANGE R. (2011), "The governance of the multinational enterprise: Insights from internalization theory”, Journal of Management Studies, vol. 48, n. 2, pp. 460-470.

BUCKLEY P.J., STRANGE R. (2015), “The governance of the global factory: Location and control of world economic activity", Academy of Management Perspectives, vol. 29, n. 2, pp. 237-249.

BULBOZ M. (2001), "Family as source, user, and builder of social capital", Journal of Socio-Economics, vol. 30, n. 2, pp. 129-131.

BURT R.S. (2000), "The network structure of social capital", Research in Organizational Behavior, vol. 22, pp. 345-423.

CAMPOPIANO G., RONDI E. (2019), "Hierarchical dyadic congruence in family firms: The interplay of supervisor and supervisee socioemotional wealth importance and familial status", Entrepreneurship Theory and Practice, vol. 43, n. 2, pp. 322-329. 
CARNEY M. (2005), "Corporate governance and competitive advantage in familycontrolled firms”, Entrepreneurship Theory and Practice, vol. 29, n. 3, pp. 249-265.

CARR C., BATEMAN S. (2009), "International strategy configurations of the world's top family firms", Management International Review, vol. 49, n. 6, pp. 733-758.

CASSON M. (1989), "A theory of cooperation in international business". In: Buckley P. (eds), The Multinational Enterprise, Palgrave Macmillan, London

CESINGER B., HUGHES M., MENSCHING H., BOUNCKEN R., FREDRICH V., KRAUS S. (2016), "A socioemotional wealth perspective on how collaboration intensity, trust, and international market knowledge affect family firms' multinationality", Journal of World Business, vol. 51, n. 4, pp. 586-599.

CHUA J.H., CHRISMAN J.J., SHARMA P. (1999), "Defining the family business by behavior", Entrepreneurship Theory and Practice, vol. 23, n. 4, pp. 19-39.

CLAVER E., RIENDA L., QUER D. (2009), "Family firms' international commitment: The influence of family-related factors", Family Business Review, vol. 22, n. 2, pp. 125-135.

COASE R.H. (1937), “The nature of the firm”, economica, vol. 4, n. 16, pp. 386-405.

COLEMAN J.S. (1988), "Social capital in the creation of human capital", American Journal of Sociology, vol. 94, pp. S95-S120.

DEBELLIS F., DE MASSIS A., PETRUZZELLI A.M., FRATTINI F., DEL GIUDICE M. (2020), "Strategic agility and international joint ventures: The willingness-ability paradox of family firms", Journal of International Management, in press. https://doi.org/10.1016/j.intman.2020.100739

DE MASSIS A., CHIRICO F., KOTLAR J., NALDI L. (2014), "The temporal evolution of proactiveness in family firms: The horizontal S-curve hypothesis", Family Business Review, vol. 27, n. 1, pp. 35-50.

DE MASSIS A., FRATTINI F., MAJOCCHI A., PISCITELLO L. (2018), "Family firms in the global economy: Toward a deeper understanding of internationalization determinants, processes, and outcomes", Global Strategy Journal, vol. 8, n. 1, pp. 3-21.

DE MASSIS A., KOTLAR J., FRATTIN F. (2013), "Is social capital perceived as a source of competitive advantage or disadvantage for family firms? An exploratory analysis of CEO perceptions", The Journal of Entrepreneurship, vol. 22 , n. 1, pp. 15-41.

DESS G.G., SHAW J.D. (2001), "Voluntary turnover, social capital, and organizational performance", Academy of Management Review, vol. 26, n. 3, pp. 446-456.

EDDLESTON K.A., CHRISMAN J.J., STEIER L.P., CHUA J.H. (2010), “Governance and trust in family firms: An introduction", Entrepreneurship Theory and Practice, vol. 34, n. 6, pp. 1043-1056.

ENDERWICK P., BUCKLEY P.J. (2017), "Beyond supply and assembly relations: Collaborative innovation in global factory systems", Journal of Business Research, vol. 103, pp. 547-556.

ERDOGAN I., RONDI E., DE MASSIS A. (2020), "Managing the tradition and innovation paradox in family firms: A family imprinting perspective", Entrepreneurship Theory and Practice, vol. 44, n. 1, pp. 20-54. 
sinergie Vol. 38, Issue 2, 2020

FERANITA F., KOTLAR J., DE MASSIS A. (2017), "Collaborative innovation in family firms: Past research, current debates and agenda for future research", Journal of Family Business Strategy, vol. 8, n. 3, pp. 137-156.

FERNÁNDEZ Z., NIETO M.J. (2005), "Internationalization strategy of small and medium-sized family businesses: Some influential factors", Family Business Review, vol. 18, n. 1, pp. 77-89.

GARGIULO M., BENASSI M. (1999), “The Dark Side of Social Capital”. In: Leenders R.T.A.J., Gabbay S.M. (eds) Corporate Social Capital and Liability, Springer, Boston, MA

GÓMEZ-MEJÍA L.R., HAYNES K.T., NÚÑEZ-NICKEL M., JACOBSON K.J., MOYANO-FUENTES J. (2007), "Socioemotional wealth and business risks in family-controlled firms: Evidence from Spanish olive oil mills", Administrative Science Quarterly, vol. 52, n. 1, pp. 106-137.

GOMEZ-MEJIA L.R., PATEL P.C., ZELLWEGER T.M. (2018), "In the horns of the dilemma: Socioemotional wealth, financial wealth, and acquisitions in family firms", Journal of Management, vol. 44, n. 4, pp. 1369-1397.

GOTTFREDSON M., PURYEAR R., PHILLIPS S. (2005), "Strategic sourcing: From the periphery to the core", Harvard Business Review, vol. 83, n. 2, pp. 132-139.

GRAVES C., THOMAS J. (2008), "Determinants of the internationalization pathways of family firms: An examination of family influence", Family Business Review, vol. 21, n. 2, pp. 151-167.

HENNART J.F. (1982), A theory of multinational enterprise, University of Michigan Press Ann Arbor, MI.

HENNART J.F., MAJOCCHI A., FORLANI E. (2017), "The myth of the stayat-home family firm: How family-managed SMEs can overcome their internationalization limitations", Journal of International Business Studies, vol. 50, n. 5, pp. 758-782.

HITT M.A., HOSKISSON R.E., KIM H. (1997), "International diversification: Effects on innovation and firm performance in product-diversified firms", Academy of Management Journal, vol. 40, n. 4, pp. 767-798.

JOHANSON J., VAHLNE J.E. (1977), "The internationalization process of the firm-a model of knowledge development and increasing foreign market commitments", Journal of International Business Studies, vol. 8, n. 1, pp. 23 32.

JOHANSON J., VAHLNE J.E. (2009), “The Uppsala internationalization process model revisited: From liability of foreignness to liability of outsidership", Journal of International Business Studies, vol. 40, n. 9, pp. 1411-1431.

KANO L., TSANG E.W., YEUNG H.W.C. (2020), "Global value chains: A review of the multi-disciplinary literature", Journal of International Business Studies, vol. 51, n. 4, pp. 577-622.

KHANIN D., TUREL O., MAHTO R.V. (2012), "How to increase job satisfaction and reduce turnover intentions in the family firm: The family-business embeddedness perspective", Family Business Review, vol. 25, n. 4, pp. 391-408.

KOGUT B. (1985), "Designing global strategies: Comparative and competitive value-added chains", Sloan Management Review, vol. 26, n. 4, pp. 15.

KONTINEN T., OJALA A. (2010), “The internationalization of family businesses: A review of extant research", Journal of Family Business Strategy, vol. 1, n. 2, pp. 97-107. 
KOTLAR J., SIGNORI A., DE MASSIS A., VISMARA S. (2018), “Financial wealth, socioemotional wealth, and IPO underpricing in family firms: A two-stage gamble model", Academy of Management Journal, vol. 61, n. 3, pp. 10731099.

Emanuela Rondi

Francesco Debellis

Alfredo De Massis

Antonello Garzoni

Bonding and bridging

social capital in family firm

internationalization

KWON S.W., RONDI E., LEVIN D.Z., DE MASSIS A., BRASS D. (2020), "Network brokerage: An integrative review and future research agenda", Journal of Management, vol. 46, n. 6, pp. 1092-1120.

LE BRETON-MILLER I., MILLER D. (2018), "Beyond the firm: Business families as entrepreneurs", Entrepreneurship Theory and Practice, vol. 42, n. 4, pp. 527-536.

LEANA C.R., VAN BUREN H.J. (1999), "Organizational social capital and employment practices", Academy of Management Review, vol. 24, n. 3, pp. 538-555.

LI L., QIAN G., QIAN Z. (2015), "Should Small, Young Technology-Based Firms Internalize Transactions in Their Internationalization?", Entrepreneurship Theory and Practice, vol. 39, n. 4, pp. 839-862.

LIANGX., WANGL., CUIZ. (2014), "Chinese private firms and internationalization: Effects of family involvement in management and family ownership", Family Business Review, vol. 27, n. 2, pp. 126-141.

LU J.W., BEAMISH P.W. (2001), "The internationalization and performance of SMEs", Strategic Management Journal, vol. 22, n. 6-7, pp. 565-586.

LUBATKIN M.H., SCHULZE W.S., LING Y., DINO R.N. (2005), "The effects of parental altruism on the governance of family-managed firms", Journal of Organizational Behavior, vol. 26, n. 3, pp. 313-330.

MUDAMBI R. (2008), "Location, control and innovation in knowledge-intensive industries", Journal of Economic Geography, vol. 8, n. 5, pp. 699-725.

OH H., CHUNG M. H., LABIANCA G. (2004), "Group social capital and group effectiveness: The role of informal socializing ties", Academy of Management Journal, vol. 47, n. 6, pp. 860-875.

ORTH U.R., GREEN M.T. (2009), "Consumer loyalty to family versus nonfamily business: The roles of store image, trust and satisfaction", Journal of Retailing and Consumer Services, vol. 16, n. 4, pp. 248-259.

PEARSON A.W., CARR J.C., SHAW J.C. (2008), “Toward a Theory of Familiness: A Social Capital Perspective", Entrepreneurship Theory and Practice, vol. 32, n. 6, pp. 949-969.

POPPO L., ZENGER T. (2002), "Do formal contracts and relational governance function as substitutes or complements?", Strategic Management Journal, vol. 23 , n. 8, pp. 707-725.

PRAHALAD C.K., HAMEL G. (1990), "Core competency concept", Harvard Business Review, vol. 64, n. 3, pp. 70-92.

PUKALL T.J., CALABRÒ A. (2014), "The internationalization of family firms: A critical review and integrative model", Family Business Review, vol. 27, n. 2, pp. 103-125.

PUTHUSSERRY P., CHILD J., KHAN Z. (2020), “Social capital development through the stages of internationalization: Relations between British and Indian SMEs", Global Strategy Journal, n. 10, pp. 282-308.

REUBER A.R. (2016), "An Assemblage-Theoretic Perspective on the Internationalization Processes of Family Firms", Entrepreneurship Theory and Practice, vol. 40, n. 6, pp. 1269-1286. 
sinergie Vol. 38, Issue 2, 2020

RONDI E., DE MASSIS A., KOTLAR J. (2019), “Unlocking innovation potential: A typology of family business innovation postures and the critical role of the family system", Journal of Family Business Strategy, vol. 10, n. 4, pp. 1-13.

RUGMAN A. (1981), "Inside the multinationals: the economics of the multinational enterprise", Inside the multinationals: The economics of the multinational enterprise, City: Columbia University Press, New York.

RUGMAN A.M. (1980), "A new theory of the multinational-enterpriseinternationalization versus internalization", Columbia Journal of World Business, vol. 15, n. 1, pp. 23-29.

SCHULZE W.S., LUBATKIN M.H., DINO R.N. (2003), “ Toward a theory of agency and altruism in family firms", Journal of Business Venturing, vol. 18, n. 4, pp. 473-490.

SHARMA P.(2008), "Commentary: Familiness: Capital stocks and flows between family and business", Entrepreneurship Theory and Practice, vol. 32, n. 6, pp. 971-977.

SIRMON D.G., HITT M.A. (2003), “Managing resources: Linking unique resources, management, and wealth creation in family firms", Entrepreneurship Theory and Practice, vol. 27, n. 4, pp. 339-358.

SORENSON R.L. (2013), Family business and social capital, Edward Elgar Publishing.

STOIAN M.C., DIMITRATOS P., PLAKOYIANNAKI E. (2018), "SME internationalization beyond exporting: A knowledge-based perspective across managers and advisers", Journal of World Business, vol. 53, n. 5, pp. 768-779.

STRANGE R., HUMPHREY J. (2019), "What lies between market and hierarchy? Insights from internalization theory and global value chain theory", Journal of International Business Studies, vol. 50, n. 8, pp. 1401-1413.

SUNDARAMURTHY C. (2008), "Sustaining trust within family businesses", Family Business Review, vol. 21, n. 1, pp. 89-102.

TALLMAN S., LI J. (1996), "Effects of international diversity and product diversity on the performance of multinational firms", Academy of Management Journal, vol. 39, n. 1, pp. 179-196.

VERBEKE A., KANO L. (2016), "An internalization theory perspective on the global and regional strategies of multinational enterprises", Journal of World Business, vol. 51, n. 1, pp. 83-92.

WILLIAMSON O.E. (1975), Markets and Hierarchies: Analysis and Antitrust implications, New York, 2630.

WILLIAMSON O.E. (1979), "Transaction-cost economics: the governance of contractual relations", The Journal of Law and Economics, vol. 22, n. 2, pp. 233-261.

WILLIAMSON O.E. (1991), "Comparative economic organization: The analysis of discrete structural alternatives", Administrative Science Quarterly, vol. 36, n. 2, pp. 269-296.

ZAHRA S. A. (2003), "International expansion of US manufacturing family businesses: The effect of ownership and involvement", Journal of Business Venturing, vol. 18, n. 4, pp. 495-512.

ZAHRA S.A. (2010), "Harvesting family firms' organizational social capital: A relational perspective", Journal of Management Studies, vol. 47, n. 2, pp. 345-366. 
ZAHRA S.A. (2018), “Technological capabilities and international expansion: the Emanuela Rondi Francesco Debellis moderating role of family and non-family firms' social capital”, Asia Pacific Journal of Management, vol. 37, n. 2, pp. 391-425.

Alfredo De Massis

Antonello Garzoni

Bonding and bridging

social capital in family firm

internationalization

\section{Academic or professional position and contacts}

\section{Emanuela Rondi}

Assistant Professor of Management

Free University of Bozen-Bolzano - Italy

e-mail: Emanuela.Rondi@unibz.it

\section{Francesco Debellis}

Post-Doctoral Researcher

Free University of Bozen-Bolzano - Italy

email: francesco.debellis@unibz.it

\section{Alfredo De Massis}

Full Professor of Management

Free University of Bozen-Bolzano - Italy

e-mail: alfredo.demassis@unibz.it

\section{Antonello Garzoni}

Full Professor of Business Administration

LUM Jean Monnet University - Italy

e-mail: garzoni@lum.it 